\title{
Botrylactone: new interest in an old molecule-review of its absolute configuration and related compounds
}

\author{
Javier Moraga, Cristina Pinedo, Rosa Durán-Patrón, Isidro G. Collado, Rosario Hernández-Galán* \\ Departamento de Química Orgánica, Facultad de Ciencias, UCA, Polígono Rio San Pedro s/n, 11510 Puerto Real, Cádiz, Spain
}

\section{A R T I C L E I N F O}

\section{Article history:}

Received 9 September 2010

Received in revised form 3 November 2010

Accepted 4 November 2010

Available online 11 November 2010

\begin{abstract}
A B S T R A C T
The absolute configuration of botrylactone, a unique compound with an interesting polyketide lactone skeleton with two oxirane bridges previously isolated from Botrytis cinerea and described as a powerful antibiotic, has been reviewed on the basis of sign of the optical rotation, NOE experiments and NMR method. The isolation of 7-deoxybotrylactone and 5-hydroxy-7-(4-hydroxydec-2(3)-enoyl) botrylactone enables us to characterize an intriguing new family of compounds with this interesting polyketide skeleton. A common biosynthetic origin with botcinin derivatives is proposed.
\end{abstract}

(c) 2010 Elsevier Ltd. All rights reserved.

\section{Introduction}

Botrytis cinerea is a well-known pathogen affecting a number of commercial crops, which produces several structurally unique metabolites. Botrytis produces two series of phytotoxic metabolites: a family of characteristic sesquiterpene metabolites with the basic botryane skeleton, principally botrydial and dihydrobotrydial and a family of polyketide lactones. The first isolated polyketide was reported by Cutler in 1993 who called it botcinolide (1), proposing a highly hydroxylated nonanolactone structure. ${ }^{1}$ Based on botcinolide structures and in addition to other botcinolide metabolites, we described ${ }^{2}$ new metabolites and investigated the biosynthesis of the botcinolide skeleton. ${ }^{3}$

In 2005, Nakajima's group reported the isolation of a group of antifungal metabolites, which they designated as botcinins. ${ }^{4}$ The absolute configuration of botcinin A (2) was determined through the modified Mosher method. A careful reinvestigation of the spectroscopic data reported for botcinolide analogues allowed them to revise the structures of botcinolide derivatives to botcinic (3) and botcineric (4) acids and their cyclized derivatives, botcinins A-F. ${ }^{5}$ Ultimately, the revised structures of this group of natural products were unequivocally determined by total synthesis ${ }^{6}$ and a revision comparing the botcinolides with their corresponding botcinin structures has been reported. ${ }^{7}$

Recently, a genetically modified strain of $B$. cinerea, $\Delta b c b o t 2$, which is unable to produce botryanes but significantly overproduces botcinic acid (3) and its derivatives was constructed. ${ }^{8}$ The higher production capacities of this strain prompted us to reinvestigate the

\footnotetext{
* Corresponding author. Tel.: +34 956016371; fax: +34 956 016193; e-mail address: rosario.hernandez@uca.es (R. Hernández-Galán).
}

metabolites produced by it. Additionally, in the course of our investigation on biotransformation with a wild strain of $B$. cinerea (UCA 992 ), a new metabolite with a botrylactone skeleton was isolated. This paper focuses on the characterization and biosynthetic route proposal of an intriguing new family of compounds, botrylactones, which could be an intermediate in the biosynthesis to botcinins. Additionally, the absolute configuration of botrylactone (6) and the structure of 2epihomobotcinolide (5) are revised.

\section{Results and discussion}

Botrylactone is a unique C-9 polyhydroxylated lactone described as a powerful antibiotically active compound reported by Welmar et al. $^{9}$ Several unsuccessful attempts to isolate this intriguing compound have been made and some of them reported. ${ }^{10}$ Recently we isolated it from the $B$. cinerea cat 2 strain. $^{3}$

Isolation of botrylactone together with botcinins, ${ }^{3}$ and the similarity of their spectroscopic data, led us to believe that they are closely related metabolites. However, comparison of the stereochemistry proposed for botrylactone $(\mathbf{6})$ and that proposed for botcinin A (2) turned out be diametrically opposed. These data, together with the overproducer mutant $\Delta b c b o t 2$, prompted us to conduct a study of $\mathbf{6}$ focusing on botcinic acid derivatives.

The Botrytis cinerea mutant, $\Delta b c b o t 2$, was cultured on malt agar medium at $24-26{ }^{\circ} \mathrm{C}$ for 7 days. The fermentation broth, after filtration and extraction was purified following the methodology described in the Experimental section. In addition to botcinin A (2) and B (7), (+)-botrylactone (11) and 3-acetylbotcineric acid (8), a metabolite whose spectroscopic and physical constants were identical to those described for 2-epihomobotcinolide $(\mathbf{5})^{3}$ and a new compound with a botrylactone skeleton, 5-hydroxy-7-(4hydroxydec-2(3)-enoyl)botrylactone (12), were isolated. 
A careful spectroscopic study of the physical constants of $\mathbf{5}$ and its comparison with those of botcinin derivatives described in the literature showed that the ${ }^{1} \mathrm{H}$ NMR and ${ }^{13} \mathrm{C}$ NMR of $\mathbf{5}$ were very similar to those of botcinin E (9). ${ }^{5}$ The ${ }^{13} \mathrm{C}$ NMR, including DEPT data, showed that $\mathbf{5}$ has two more methylenes than $\mathbf{9}$. The fragment ion assignable to the fatty acyl portion was detected at $\mathrm{m} / \mathrm{z} 169$, which is characteristic of a $\mathrm{C}_{10} \mathrm{H}_{16} \mathrm{O}$. Thus, $\mathbf{5}$ differ from $\mathbf{9}$ in the length of the acyl portion. The key NOE correlations were identical to those of $\mathbf{9}$ indicating that $\mathbf{5}$ and $\mathbf{9}$ share the same relative stereochemistry. Therefore, the structure of 2-epihomobotcinolide (5) should be revised to $\mathbf{1 0}$ and renamed as botcinin G.

Botrylactone was reported for the first time by Welmar et al. ${ }^{9}$ who initially proposed structure $\mathbf{6 a}$ based on spectroscopic data. Although they used the term, 'absolute configuration' in the text of the paper, they did not determine the absolute configuration but its relative configuration by X-ray diffraction of its acetate derivative (6b). ${ }^{9}$ Later, Redlich et al. synthesized it and revised the originally published structure to 7-OH $\alpha$-botrylactone $(\mathbf{6}){ }^{11}$

The optical rotation of natural botrylactone had not been previously reported. Welmar et al. prepared acetyl botrylactone and reported its optical rotation as $+88\left(c 1, \mathrm{CHCl}_{3}\right),{ }^{9}$ while Redlich et al. described it for synthetic botrylactone $(\mathbf{6})$ as $-31(c 0.14, \mathrm{MeOH}){ }^{11}$

The isolation of a sufficient amount of natural botrylactone from $\Delta b c b o t 2$ has enabled us to measure its optical rotation determined as +19 (c 2.6, $\mathrm{CHCl}_{3}$ ), the opposite sign of that described for the synthetic compound. Acetylation of it led us to a product whose spectroscopic data were identical to those described for natural acetyl botrylactone whose optical rotation proved to be +73 (c $2.4 \mathrm{mg}$, $\mathrm{CHCl}_{3}$ ), coinciding with the sign described by Welmar et al. ${ }^{9}$ As a result, it can be inferred that the structure synthesized by Redlich et al. should be the enantiomeric to the natural compound, (-)-botrylactone (6). In order to confirm this hypothesis we determined the absolute configuration of natural $(+)$-botrylactone using the NMR method. (+)-Botrylactone was treated with $R(-)$ and $S$ (+)-MPA acid yielding the corresponding $R$ and $S$-MPA esters 11a and 11b, respectively. Comparison of the chemical shifts in ${ }^{1} \mathrm{H}$ NMR spectra of the two compounds showed a negative $\Delta \delta^{\mathrm{RS}}$ value for $\mathrm{C}_{8}-\mathrm{CH}_{3}$ and $\mathrm{C}_{9}-\mathrm{CH}_{3},(-0.57$ and $-0.26 \mathrm{ppm}$, respectively), while the $\Delta \delta^{\mathrm{RS}}$ for $\mathrm{H}-6$ and $\mathrm{C}_{6}-\mathrm{CH}_{3}$ were positive ( 0.11 and $\left.0.47 \mathrm{ppm}\right)$. Application of the Mosher rule ${ }^{12}$ showed a $7 R$ configuration for esterificated products 11a and hence for $(+)$ - botrylactone (11).

The stereochemistry of the rest of the chiral carbons was confirmed on the basis of NOE data (Fig. 1). Irradiation of the $\mathrm{H}-7$ signal of compound 11a produced NOE enhancement of $\mathrm{H}-5 \alpha, \mathrm{C}_{6}-\mathrm{CH}_{3}$ and $\mathrm{C}_{9}-\mathrm{CH}_{3}$, establishing a boat conformation for this tetrahydropyran ring, which was confirmed by irradiation of $\mathrm{H}-5 \beta$ that enhanced the

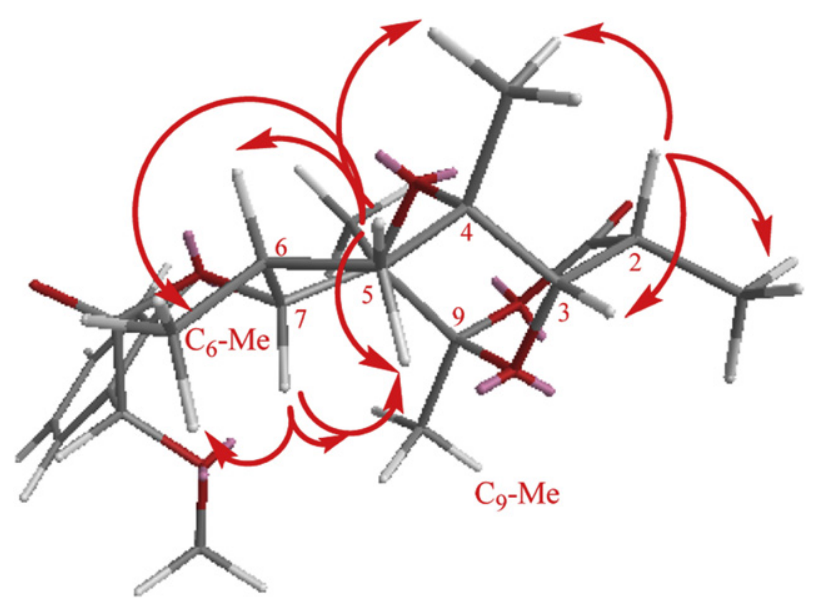

Fig. 1. NOEs interactions in 11a. signals of $\mathrm{H}-6, \mathrm{C}_{6}-\mathrm{Me}, \mathrm{C}_{4}-\mathrm{Me}$ and $\mathrm{H}-5 \alpha$. A quasi-boat conformation was established for pentanolide ring on the basis of NOE enhancement of $\mathrm{C}_{2}-\mathrm{Me}, \mathrm{C}_{4}-\mathrm{Me}$ and $\mathrm{H}-3$ observed when $\mathrm{H}-2$ was irradiated. These data coincide with a configuration where $\mathrm{H}-2, \mathrm{C}_{4}-\mathrm{Me}$ and $\mathrm{C}_{8}-$ Me were on the $\beta$ face and $\mathrm{H}-3, \mathrm{H}-7, \mathrm{C}_{6}-\mathrm{Me}$ and $\mathrm{C}_{9}-\mathrm{CH}_{3}$ were on the $\alpha$. The absolute stereochemistry of natural botrylactone, $(+)-\mathbf{1 1}$, was definitively established as $2 R, 3 S, 4 S, 6 S, 7 R, 8 R, 9 R$.

Compound 12 was isolated as an oil whose molecular formula was established as $\mathrm{C}_{24} \mathrm{H}_{38} \mathrm{O}_{8}$ by HRMS and ${ }^{13} \mathrm{C}$ NMR data requiring $6^{\circ}$ of unsaturation. Its ${ }^{1} \mathrm{H}$ NMR spectrum was very similar to that of botcinins however the presence of a signal in ${ }^{13} \mathrm{C} N M R$ at $\delta 104.2 \mathrm{ppm}$, attributable to a ketal group plus an additional methyl group, should correspond to an additional $\mathrm{C}_{2}$ unit resulting in a structure similar to that of botrylactone (11). However, the ${ }^{1} \mathrm{H}$ NMR showed signals at ${ }_{H} 7.00,6.07$ and 4.33 ppm characteristic of the fatty acyl portion on C-7 of botcinins. The fragment ion detected at $m / z$ 169 was characteristic of a fatty acyl chain with molecular formula $\mathrm{C}_{10} \mathrm{H}_{16} \mathrm{O}$. The HMBC experiment performed on 12 showed correlations between the quaternary ketalic carbon signal $\left(\delta_{\mathrm{C}} 104.2 \mathrm{ppm}\right)$, two methyl singlet groups ( $\delta_{\mathrm{H}} 1.53$ and $1.10 \mathrm{ppm}$ ), which were further correlated with a quaternary oxygenated carbon at $\delta_{\mathrm{C}} 79.2 \mathrm{ppm}$ and two signals at $\delta_{\mathrm{H}} 4.93$ and $3.52 \mathrm{ppm}$ attributable to $\mathrm{H}-7$ and $\mathrm{H}-3$, respectively (Fig. 2). H-3 was further correlated with signal at $\delta_{\mathrm{C}}$ 171.0 ppm corresponding to carbon $\mathrm{C}-1$ while $\mathrm{H}-7$ exhibited correlation with the carbon signal at $\delta_{\mathrm{C}} 165.4 \mathrm{ppm}$ corresponding to the $\mathrm{C}$ 1 of the fatty acyl portion. Additional correlations were observed between carbon $\mathrm{C}-3\left(\delta_{\mathrm{C}} 80.9 \mathrm{ppm}\right)$ and two methyl groups at $\delta_{\mathrm{H}} 1.46$ (d) and 1.14 (s) ppm. The COSY experiment showed correlations between the signal doublet at $\delta_{\mathrm{H}} 4.93 \mathrm{ppm}(\mathrm{H}-7)$ and a multiplet at $\delta_{\mathrm{H}}$ $1.86 \mathrm{ppm}$, which was further correlated with two doublets at $\delta_{\mathrm{H}}$ $3.67 \mathrm{ppm}$ and $1.02 \mathrm{ppm}$, pointing to the presence of a fragment $\mathrm{O}-\mathrm{CH}-\mathrm{CH}\left(\mathrm{CH}_{3}\right)-\mathrm{CH}-\mathrm{O}$ in the molecule. All these data are consistent with a structure of 5-hydroxybotrylactone bearing a fatty acyl chain on C-7 for this compound. The stereochemistry was determined by N.O.E experiments and was consistent with the stereochemistry assigned to compound $\mathbf{1 1}$ confirming the structure of $2 R, 3 S, 4 S, 5 S, 6 S, 7 R, 8 R, 9 R$-5-hydroxy-7-(4-hydroxydec-2(3)-enoyl) botrylactone for compound $\mathbf{1 2}$.

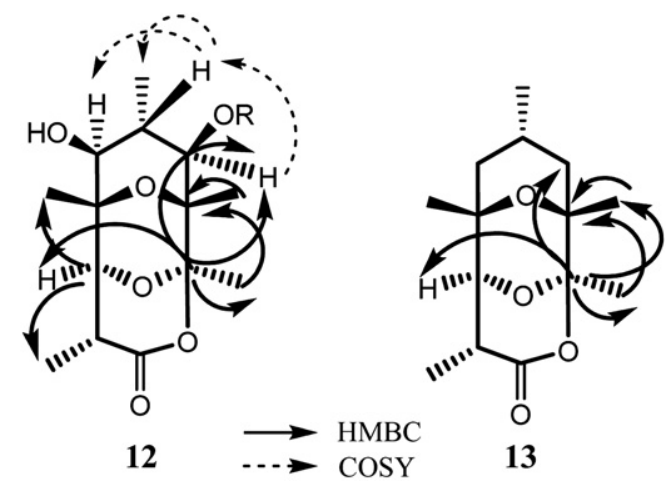

Fig. 2. Selected HMBC-COSY correlations for $\mathbf{1 2}$ and 13.

Furthermore, during the course of our biotransformation experiments with $B$. cinerea UCA $992^{13}$ we found a new compound 13 with an NMR pattern very similar to that of $(+)$-botrylactone (11), the principal difference being the absence of the characteristic $\mathrm{H}-7$ signal in its ${ }^{1} \mathrm{H}$ NMR spectrum and one of the carbon bearing to oxygen and the presence of a signal corresponding to one more methylene in the ${ }^{13} \mathrm{C}$ NMR spectrum. Therefore, $\mathbf{1 3}$ differ from $\mathbf{1 1}$ in the absence of the hydroxyl group on C-7. HRMS confirms this showing an ion assignable to $\mathrm{C}_{13} \mathrm{H}_{22} \mathrm{O}_{3}[\mathrm{M}-\mathrm{CO}]^{+}$at $\mathrm{m} / \mathrm{z} 226.1573$. The botrylactone skeleton was confirmed by the 2D NMR data where correlation in the HMBC experiment between the characteristic 
quaternary carbon signal $\left(\delta_{\mathrm{C}} 104.8 \mathrm{ppm}\right)$ and signals corresponding to $\mathrm{H}-3, \mathrm{H}_{2}-7$ and two methyl singlet groups, which were further correlated with C-8 were observed. The key NOE correlations were identical to those of 11a, indicating that $\mathbf{1 1}$ and $\mathbf{1 3}$ share the same relative stereochemistry. On the basis of these data the structure of 13 was suggested to be $2 R, 3 S, 4 S, 6 S, 8 R, 9 R-7-$ dehydroxybotrylactone.

The occurrence of botrylactone derivatives and botcinins in the same strain, their structural homology, the resulting absolute configuration of natural botrylactone (11) therefore being identical to that assigned to botcinins by Nakajima ${ }^{4}$ except in C-8, seems to indicate that both compounds may be biogenetically related.

Incorporation studies with ${ }^{13} \mathrm{C}$ and ${ }^{2} \mathrm{H}$-labelled precursors conducted by our group ${ }^{3}$ indicated that 3-O-acetylhomobotcinolide (14) was an acetate derived polyketide whose methyl groups originate from $C$-methyl methionine. This conclusion is applicable to its revised structure, $\mathbf{8}$, but an important question, the presence of the methyl group derived from C-methyl methionine on the C-8 carbon atom, the alleged carbon two of the starter-acetate unit, has yet to be resolved.

\section{Conclusions}

A plausible explanation for this, which has been previously reported for other natural products, such as aurovertin, ${ }^{14}$ is that $B$. cinerea biosynthesis involves a $\mathrm{C}_{10}$-polyketide, which is methylated at activated methylene groups, followed by the loss of the starteracetate unit through a retro-Claisen type $\mathrm{C}-\mathrm{C}$ bond cleavage with inversion of configuration at C-8 (Scheme 1 ).

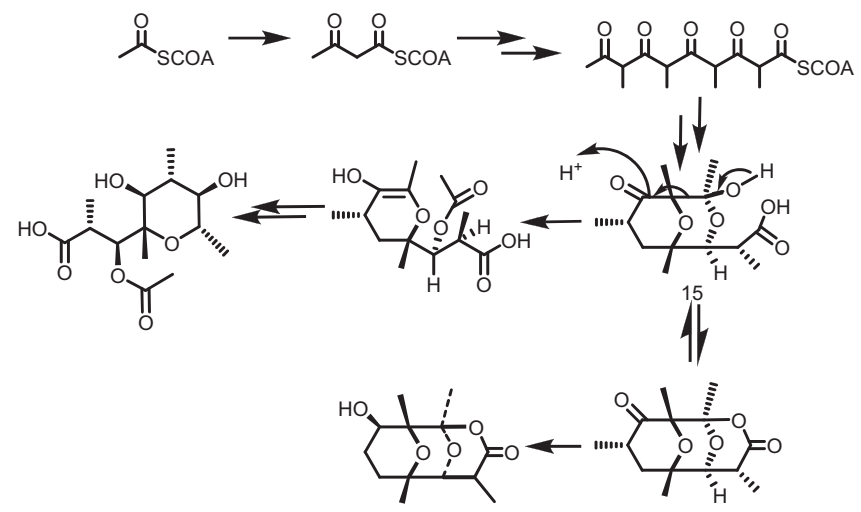

Scheme 1. Biosynthetic route proposal for botrylactones and botcinins.

This hypothesis is in agreement with the common biosynthetic origin of botrylactone (11) and botcinins, where a hypothetical bicyclic acid intermediate $\mathbf{1 5}$ could be the branching point to give botrylactone or botcinin derivatives as shown in Scheme 1. This proposal explains the presence of the methyl group on C-8 of botcinins and the different stereochemistry in this carbon.

\section{Experimental section}

\subsection{General experimental procedures}

${ }^{1} \mathrm{H}$ and ${ }^{13} \mathrm{C}$ NMR measurements were recorded on Varian Unity $400 \mathrm{MHz}$ and Varian Inova $600 \mathrm{MHz}$ spectrometers with $\mathrm{SiMe}_{4}$ as the internal reference. Chemical shifts were referenced to $\mathrm{CDCl}_{3}\left(\delta_{\mathrm{H}}\right.$ $\left.7.25, \delta_{\mathrm{C}} 77.0\right)$. HPLC was performed with a Hitachi/Merck L-6270 apparatus equipped with a differential refractometer detector (RI7490). A Lichrofer Si $60(5 \mu \mathrm{m})$ LichoCart $(250 \mathrm{~mm} \times 4 \mathrm{~mm})$ column and a Lichrofer Si $60(10 \mu \mathrm{m})$ LichoCart $(250 \mathrm{~mm} \times 10 \mathrm{~mm})$ were used in isolation experiments. Silica gel (Merck) was used for column chromatography. TLC was performed on Merck Kiesegel 60 $\mathrm{F}_{254}, 0.25 \mathrm{~mm}$ thick.

\subsection{Microorganism}

B. cinerea mutant strain, bcbot2 2 , was supplied by Dr. Muriel Viaud of the UMR BIOGER, INRA (Versailles, France). The strain was maintained viable on mycelia discs of $0.5 \mathrm{~cm}$ diameter submerged in $80 \%$ glycerol at $-40{ }^{\circ} \mathrm{C}$.

B. cinerea (UCA 992) was obtained from grapes from Domecq vineyard, Jerez de la Frontera, Cadiz, Spain. This culture is deposited at the Universidad de Cadiz, Facultad de Ciencias Mycological Herbarium Collection (UCA).

\subsection{Culture conditions}

bcbot $2 \Delta$ was grown on malt agar medium ( $20 \mathrm{~g}$ of D-glucose, $10 \mathrm{~g}$ of malt extract, $20 \mathrm{~g}$ of agar, pH 6.57 per liter of water) at $25^{\circ} \mathrm{C}$ and used to inoculate Roux bottles or Erlenmeyer flasks. For surface culture, mycelium was grown in $1 \mathrm{~L}$ Roux bottles containing $150 \mathrm{~mL}$ of modified Czapek-Dox medium (50 mg of D-glucose, $1 \mathrm{~g}$ of yeast extract, $5 \mathrm{~g}$ of $\mathrm{KH}_{2} \mathrm{PO}_{4}, 2 \mathrm{~g}$ of $\mathrm{NaNO}_{3}, 0.5 \mathrm{~g}$ of $\mathrm{MgSO}_{4} \cdot 7 \mathrm{H}_{2} \mathrm{O}$ and $0.01 \mathrm{~g}$ of $\mathrm{FeSO}_{4} \cdot 7 \mathrm{H}_{2} \mathrm{O}$, pH 6.57.0 per liter of water) at room temperature. For shaken cultures, mycelium was grown in Erlenmeyer flasks containing $200 \mathrm{~mL}$ of the same medium agitated on an orbital shaker at $140 \mathrm{rpm}$ at $25^{\circ} \mathrm{C}$. Each Roux bottle or Erlenmeyer flask was inoculated with mycelium on six small slices of agar $(1 \mathrm{~cm})$.

\subsection{Extraction and isolation of metabolites}

After 7 days of incubation under fluorescent light, the culture media were filtered, saturated with $\mathrm{NaCl}$, extracted with ethyl acetate $(3 \times 0.5 \mathrm{vol})$ and washed with water $(3 \times 0.25 \mathrm{vol})$. The organic extracts were dried over $\mathrm{Na}_{2} \mathrm{SO}_{4}$ and concentrated to dryness.

Preliminary fractionation of the extracts was achieved by column chromatography eluting with petroleum ether/ethyl acetate mixtures containing increasing percentages of ethyl acetate (10-100\%) to give 10 fractions F1-F10. Final purification of each fraction was carried out by means of semi-preparative or analytical HPLC. Botcinin A (2), botcinin B (2a), botcinin G (10), 3-O-acetylbotcineric acid (8), (+)-botrylactone (11) and 5-hydroxy-7-(4hydroxydec-2(3)-enoyl)botrylactone (12) were obtained.

4.4.1. Botcinin $A(\mathbf{2})$ and $B(\mathbf{2 a})^{4}$. Compounds 2 and 2a were obtained from purification of fractions F4 and F5 as a colourless oil. Semi-preparative HPLC: hexane-ethyl acetate 70:30; flow $3 \mathrm{~mL} \mathrm{m^{-1 }} ; t_{\mathrm{R}}$ around 29 and $35 \mathrm{~min}$, respectively.

4.4.2. Botcinin $G(\mathbf{1 0})$. Compound 10 was obtained from purification of fractions F7 as a colourless oil. Semi-preparative HPLC: hexane-ethyl acetate 75:25; flow $3 \mathrm{~mL} \min ^{-1} ; t_{\mathrm{R}}=7.0 \mathrm{~min}[\alpha]_{\mathrm{D}}^{35}$ $-34^{\circ}$ (c 2.0, $\mathrm{CHCl}_{3}$ ); IR $v_{\max }$ (film) 3452, 2933, 2870, 1723, 1652, $1456,1166 \mathrm{~cm}^{-1}$; ${ }^{1} \mathrm{H}$ NMR (400 MHz, CD $\left.3 \mathrm{OD}\right) \delta 7.02$ (dd, $1 \mathrm{H}, J=15.5$, $\left.4.9 \mathrm{~Hz}, \mathrm{H}-3^{\prime}\right), 6.05$ (dd, $1 \mathrm{H}, J=15.5,1.7 \mathrm{~Hz}, \mathrm{H}-2^{\prime}$ ), 4.50 (dd, $1 \mathrm{H}, J=10.5$, $9.7 \mathrm{~Hz}, \mathrm{H}-7), 4.25$ (m, 1H, H-4'), 4.08 (d, 1H, J=9.4 Hz, H-3), 3.94 (d, $1 \mathrm{H}, J=10.9 \mathrm{~Hz}, \mathrm{H}-5$ ), 3.77 (dq, 1H, J=9.7, $5.9 \mathrm{~Hz}, \mathrm{H}-8$ ), 3.20 (dq, $1 \mathrm{H}$, $J=9.4,7.3 \mathrm{~Hz}, \mathrm{H}-2), 2.21(\mathrm{~m}, 1 \mathrm{H}, J=10.5,6.4 \mathrm{~Hz}, \mathrm{H}-6), 1.49$ (m, 2H, H$\left.5^{\prime}\right), 1.31\left(\mathrm{~m}, 2 \mathrm{H}, \mathrm{H}-5^{\prime}\right), 1.17\left(\mathrm{~m}, 6 \mathrm{H}, \mathrm{H}-7^{\prime}, \mathrm{H}-8^{\prime}, \mathrm{H}-9^{\prime \prime}\right), 1.17(\mathrm{~s}, 3 \mathrm{H}$, $\left.\mathrm{C}_{4}-\mathrm{CH}_{3}\right), 1.11\left(\mathrm{~d}, 3 \mathrm{H}, J=5.9 \mathrm{~Hz}, \mathrm{C}_{8}-\mathrm{CH}_{3}\right), 1.13(\mathrm{~d}, 3 \mathrm{H}, J=7.3 \mathrm{~Hz}$, $\left.\mathrm{C}_{2}-\mathrm{CH}_{3}\right), 1.07\left(\mathrm{~d}, 3 \mathrm{H}, J=6.4 \mathrm{~Hz}, \mathrm{C}_{6}-\mathrm{CH}_{3}\right), 0.89(\mathrm{t}, 3 \mathrm{H}, J=5.0 \mathrm{~Hz}, \mathrm{H}-$ $\left.10^{\prime}\right) ;{ }^{13} \mathrm{C}$ NMR (100 MHz, CD $\left.3 \mathrm{OD}\right) 177.4(\mathrm{~s}, \mathrm{C}-1), 167.6$ (s, C-1' $), 154.0$ (d, C-3') 119.9 (d, C-2'), 79.7 (d, C-5), 77.9 (d, C-7), 78.1 (s, C-4), 75.0 (d, C-3), 71.6 (d, C-12), 69.6 (d, C-8), 39.6 (d, C-2), 37.5 (t, C-5'), 36.8 (d, C-6), $32.9\left(\mathrm{t}, \mathrm{C}-8^{\prime}\right), 30.2\left(\mathrm{t}, \mathrm{C}-\mathrm{7}^{\prime}\right), 26.4\left(\mathrm{t}, \mathrm{C}-6^{\prime}\right), 23.6\left(\mathrm{t}, \mathrm{C}-9^{\prime}\right), 18.6$ $\left(\mathrm{q}, \mathrm{C}_{8}-\mathrm{CH}_{3}\right), 14.3\left(\mathrm{q}, \mathrm{C}-10^{\prime}\right), 13.9\left(\mathrm{q}, \mathrm{C}_{6}-\mathrm{CH}_{3}\right), 11.5\left(\mathrm{q}, \mathrm{C}_{4}-\mathrm{CH}_{3}\right), 10.4$ (q, $\mathrm{C}_{2}-\mathrm{CH}_{3}$ ); EIMS $m / z$ (rel int.) $394\left[\mathrm{M}-\mathrm{H}_{2} \mathrm{O}\right]^{+}$(9), 226 (26), 169 (9), 
140(23), 124 (83), 109 (100); HREIMS calcd for $\mathrm{C}_{22} \mathrm{H}_{34} \mathrm{O}_{6}\left[\mathrm{M}-\mathrm{H}_{2} \mathrm{O}\right]^{+}$ 394.2355 , found 394.2353 .

4.4.3. 3-O-Acetylbotcineric acid (8). Compound $\mathbf{8}$ obtained from fractions F9 and F10. Semi-preparative HPLC: hexane-ethyl acetate

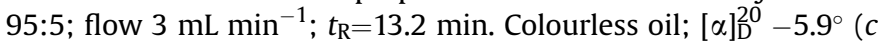
1.4 , ethyl acetate). ${ }^{15}$

4.4.4. (+)-Botrylactone (11). Compound $\mathbf{1 1}$ obtained from fractions F5. Analytical HPLC: hexane-ethyl acetate 65:35; flow $1 \mathrm{~mL} \mathrm{~min}^{-1}$; $t_{\mathrm{R}}=28.98 \mathrm{~min}$. Colourless oil; $[\alpha]_{\mathrm{D}}^{25}+19^{\circ}\left(\right.$ c $\left.2.3, \mathrm{CHCl}_{3}\right){ }^{9,11}$

4.4.5. $2 R, 3 S, 4 S, 6 S, 8 R, 9 R-5$-Hydroxy-7-(4-hydroxydec-2(3)-enoyl) botrylactone (12). Compound 12 obtained from fractions F9 and F10. Semi-preparative HPLC: hexane-ethyl acetate 95:5; flow $3 \mathrm{~mL} \mathrm{~min}{ }^{-1} ; t_{\mathrm{R}}=15.1 \mathrm{~min}$. Colourless oil; $[\alpha]_{\mathrm{D}}^{20}+10.6^{\circ}$ (c 0.9, ethyl acetate); IR $v_{\max }$ (film) 3445, 2931, 2859, 1727, 1652, 1456, $1116 \mathrm{~cm}^{-1} ;{ }^{1} \mathrm{H}$ NMR $\left(400 \mathrm{MHz}, \mathrm{CDCl}_{3}\right) \delta 7.00(\mathrm{dd}, 1 \mathrm{H}, J=15.6,4.5 \mathrm{~Hz}$, $\mathrm{H}-3^{\prime}$ ), 6.07 (dd, $1 \mathrm{H}, J=15.6,1.6 \mathrm{~Hz}, \mathrm{H}-2^{\prime}$ ), 4.93 (d, $1 \mathrm{H}, J=10.9 \mathrm{~Hz}, \mathrm{H}-7$ ), $4.33\left(\mathrm{~m}, 1 \mathrm{H}, \mathrm{H}-4^{\prime}\right), 3.67$ (d, $\left.1 \mathrm{H}, J=11.1 \mathrm{~Hz}, \mathrm{H}-5\right), 3.52$ (s, 1H, H-3), 2.75 (q, $1 \mathrm{H}, J=7.4 \mathrm{~Hz}, \mathrm{H}-2), 1.99(\mathrm{~m}, 1 \mathrm{H}, \mathrm{H}-6), 1.60\left(\mathrm{~m}, 2 \mathrm{H}, \mathrm{H}-5^{\prime}\right), 1.53$ (s, $\left.3 \mathrm{H}, \mathrm{C}_{9}-\mathrm{CH}_{3}\right), 1.46$ (d, 3H, J=7.4 Hz, $\left.\mathrm{C}_{2}-\mathrm{CH}_{3}\right), 1.28$ (m, 8H, H-6', H-7', $\left.\mathrm{H}-8^{\prime}, \mathrm{H}-9^{\prime}\right), 1.14$ (s, 3H, $\left.\mathrm{C}_{4}-\mathrm{CH}_{3}\right), 1.10$ (s, 3H, $\left.\mathrm{C}_{8}-\mathrm{CH}_{3}\right), 1.02$ (d, 3H, $\left.J=6.4 \mathrm{~Hz}, \mathrm{C}_{6}-\mathrm{CH}_{3}\right), 0.87\left(\mathrm{t}, 3 \mathrm{H}, J=6.8 \mathrm{~Hz}, \mathrm{H}-10^{\prime}\right) ;{ }^{13} \mathrm{C} \mathrm{NMR}(100 \mathrm{MHz}$, $\left.\mathrm{CDCl}_{3}\right) 171.0$ (s, C-1), 165.4 (s, C-1'), 151.9 (d, C-3'), 119.0 (d, C-2'), 104.2 (s, C-9), 80.9 (d, C-3), 79.2 (s, C-8), 76.2 (s, C-4), 75.1 (d, C-5), 74.2 (d, C-7), 71.1 (d, C-4'), 36.7 (d, C-5'), 36.5 (t, C-6'), 34.5 (d, C-2), $31.6\left(\mathrm{t}, \mathrm{C}-8^{\prime}\right), 29.1\left(\mathrm{t}, \mathrm{C}-7^{\prime}\right), 25.2\left(\mathrm{t}, \mathrm{C}-6^{\prime}\right), 22.5\left(\mathrm{t}, \mathrm{C}-9^{\prime}\right), 21.7(\mathrm{q}$, $\left.\mathrm{C}_{9}-\mathrm{CH}_{3}\right), 18.5$ (q, $\left.\mathrm{C}_{2}-\mathrm{CH}_{3}\right), 18.2\left(\mathrm{q}, \mathrm{C}_{4}-\mathrm{CH}_{3}\right), 18.1$ (q, $\left.\mathrm{C}_{8}-\mathrm{CH}_{3}\right), 14.0$ $\left(\mathrm{q}, \mathrm{C}-10^{\prime}\right), 13.8\left(\mathrm{q}, \mathrm{C}_{6}-\mathrm{CH}_{3}\right)$; EIMS $m / z$ (rel int.) $454[\mathrm{M}]^{+}(1), 426$ $[\mathrm{M}-\mathrm{CO}]^{+}(7), 410\left[\mathrm{M}-\mathrm{CO}_{2}\right]^{+}(6)$; HREIMS calcd for $\mathrm{C}_{23} \mathrm{H}_{38} \mathrm{O}_{7}$ $[\mathrm{M}-\mathrm{CO}]^{+}$426.2618, found 426.2641 .

\subsection{Acetylation of botrylactone}

Botrylactone $(\mathbf{1 1}, 10 \mathrm{mg})$ was dissolved in dry pyridine $(1 \mathrm{~mL}$, $0.001 \mathrm{mmol}$ ) and acetic anhydride $(2.4 \mathrm{~mL}, 24,6 \mathrm{mmol})$ was added dropwise. The reaction mixture was stirred for $24 \mathrm{~h}$. Then the solvent was removed and the crude reaction product chromatographed to give botrylactone acetate (11c). Colourless oil; $[\alpha]_{D}^{25}+73,\left(\right.$ c $\left.2.4 \mathrm{mg}, \mathrm{CHCl}_{3}\right){ }^{9}$

\section{6. $\alpha$-Methoxyphenylacetyl ester of botrylactone}

A solution of the botrylactone $(\mathbf{1 1}, 10 \mathrm{mg}, 0.037 \mathrm{mmol})$ in dry dichloromethane $\mathrm{CH}_{2} \mathrm{Cl}_{2}(1.5 \mathrm{~mL})$ was treated with DMAP $(9.05 \mathrm{mg}$, 2.0 equiv) and ( + -) $(2 S)$ - or (-)-(2R)-2-methoxy-2-phenylacetic acid MPA (13.85 mg, 2.25 equiv). After 15 min stirring at room temperature, EDC (14.91 mg, 2.1 equiv) was added. Stirring was maintained for $24 \mathrm{~h}$. The solvent was stirred under reduced pressure. Residue purification was achieved by flash column chromatography on silica gel (elution with 60:40 hexane/ethyl acetate).

4.6.1. (R)- $\alpha$-Methoxyphenylacetyl ester of botrylactone (11a). ${ }^{1} \mathrm{H}$ $\operatorname{NMR}\left(400 \mathrm{MHz}, \mathrm{CDCl}_{3}\right) \delta 7.40$ and $7.33\left(\mathrm{~m}, 2 \mathrm{H}\right.$ and $\left.3 \mathrm{H}, \mathrm{C}_{2^{\prime}}-\mathrm{Ph}\right), 4.87$ (d, $1 \mathrm{H}, J=10.8 \mathrm{~Hz}, \mathrm{H}-7$ ), 4.75(s, $1 \mathrm{H}, \mathrm{H}-2^{\prime}$ ), 3.39 (s, 3H, $\mathrm{C}_{2^{\prime}}-\mathrm{OMe}$ ), 3.27 (br s, 1H, H-3), 2.63 (q, 1H, J=7.3 Hz, H-2), 1.90 (m, 1H, H-6), 1.71 (dd, $J=4.7,13.5 \mathrm{~Hz}, \mathrm{H}-5 \beta), 1.55$ (dt, $J=2.7,13.2 \mathrm{~Hz}, \mathrm{H}-5 \alpha), 1.39(\mathrm{~d}, 3 \mathrm{H}$, $\left.J=7.3 \mathrm{~Hz}, \mathrm{C}_{2}-\mathrm{CH}_{3}\right), 1.26\left(\mathrm{~s}, 3 \mathrm{H}, \mathrm{C}_{9}-\mathrm{CH}_{3}\right), 1.12\left(\mathrm{~s}, 3 \mathrm{H}, \mathrm{C}_{8}-\mathrm{CH}_{3}\right), 0.91(\mathrm{~d}$, $\left.3 \mathrm{H}, J=6.4 \mathrm{~Hz}, \mathrm{C}_{6}-\mathrm{CH}_{3}\right), 0.86\left(\mathrm{t}, 3 \mathrm{H}, J=7.2 \mathrm{~Hz}, \mathrm{H}-10^{\prime}\right)$.

4.6.2. (S)- $\alpha$-Methoxyphenylacetyl ester of botrylactone (11b). ${ }^{1} \mathrm{H}$ $\operatorname{NMR}\left(400 \mathrm{MHz}, \mathrm{CDCl}_{3}\right) \delta 7.44$ and $7.38\left(\mathrm{~m}, 2 \mathrm{H}\right.$ and $3 \mathrm{H}, \mathrm{C}_{2^{\prime}}-\mathrm{Ph}$ ), 4.81 (d, $1 \mathrm{H}, J=10.8 \mathrm{~Hz}, \mathrm{H}-7$ ), 4.76(s, $1 \mathrm{H}, \mathrm{H}-2^{\prime}$ ), 3.40 (s, 3H, $\mathrm{C}_{2^{\prime}}-\mathrm{OMe}$ ), 3.27 (br s, 1H, H-3), 2.67 (q, 1H, J=7.3 Hz, H-2), 1.79 (m, 1H, H-6), 1.62 (dd, $J=5.0,13.5 \mathrm{~Hz}, \mathrm{H}-5 \beta), 1.55(\mathrm{t}, J=13.2 \mathrm{~Hz}, \mathrm{H}-5 \alpha), 1.52\left(\mathrm{~s}, 3 \mathrm{H}, \mathrm{C}_{9}-\mathrm{CH}_{3}\right)$, 1.42(d, 3H, J=7.3 Hz, $\left.\mathrm{C}_{2}-\mathrm{CH}_{3}\right), 1.12\left(\mathrm{~s}, 3 \mathrm{H}, \mathrm{C}_{4}-\mathrm{CH}_{3}\right), 1.04(\mathrm{~s}, 3 \mathrm{H}$, $\left.\mathrm{C}_{8}-\mathrm{CH}_{3}\right), 0.44\left(\mathrm{~d}, 3 \mathrm{H}, \mathrm{J}=6.4 \mathrm{~Hz}, \mathrm{C}_{6}-\mathrm{CH}_{3}\right)$.

\subsection{Biotransformation of 2-benzylideneindan-1-one}

Botrytis cinerea UCA 992 was grown at $25^{\circ} \mathrm{C}$ on a Czapeck-Dox medium (200 $\mathrm{mL}$ per flask). The shaken culture was incubated in an orbital shaker at $140 \mathrm{rpm}$ under fluorescent light. 2-Benzylideneindan-1-one was dissolved in ethanol and then distributed over 12 flasks ( $150 \mathrm{ppm}$ per flask) and the fermentation continued for 5 days in six flasks and 10 days in the others. The mycelium was then filtered and the broth was extracted as described below. The solvent was then evaporated and the residue was purified first on a silica gel column and then with HPLC with an increasing gradient of ethyl acetate to petroleum ether.

Chromatography of the extract fermented for 5 days produced 2-benzylideneindan-1-one (4 $\mathrm{mg}), \quad O$-methyldihydrobotrydial (3.2 mg), botrydial (4 mg), dihydrobotrydial (3 mg), 7-deoxybotrylactone $(13,2.8 \mathrm{mg})$ and 2-( $p$-hydroxyphenylmethyl)indan-1one $(50 \mathrm{mg})\left([\alpha]_{\mathrm{D}}^{20}+6^{\circ}(c 0.1, \mathrm{MeOH}), 36 \%\right.$ ee $)$.

Chromatography of the extract fermented for 10 days produced 2-benzylideneindan-1-one (14 mg), botrydial (2 mg), dihydrobotrydial ( $3 \mathrm{mg}), 7$-deoxybotrylactone (13,15.3 mg), botcinic acid (3, $60 \mathrm{mg}$ ) and 2-(p-hydroxyphenylmethyl)-7-hydroxyindan-1-one $(17 \mathrm{mg})[\alpha]_{\mathrm{D}}^{20}-3.7^{\circ}(c \mathrm{c}, 1, \mathrm{MeOH}, 7 \%$ ee $)$.

4.7.1. 7-Deoxybotrylactone (13). Compound $\mathbf{1 3}$ obtained from fraction F3. Column chromatography: hexane-ethyl acetate 80:20. Amorphous solid; $[\alpha]_{\mathrm{D}}^{25}+2.45^{\circ}\left(\mathrm{c} 0.3 \mathrm{CHCl}_{3}\right)$; IR $v_{\max }$ (film) $2925,1735,1459$, 1103, $950 \mathrm{~cm}^{-1}$; ${ }^{1} \mathrm{H}$ NMR (400 MHz, $\left.\mathrm{CDCl}_{3}\right) \delta 3.28(\mathrm{~s}, 1 \mathrm{H}, \mathrm{H}-3), 2.70(\mathrm{q}$, $1 \mathrm{H}, J=7.3 \mathrm{~Hz}, \mathrm{H}-2), 1.75$ (m, 1H, H-6), $1.63(\mathrm{~m}, 1 \mathrm{H}, \mathrm{H}-5), 1.57$ ( $\mathrm{m}, 2 \mathrm{H}, \mathrm{H}-$ 7) $1.44\left(\mathrm{~s}, 3 \mathrm{H}, \mathrm{C}_{9}-\mathrm{CH}_{3}\right), 1.40\left(\mathrm{~d}, 3 \mathrm{H}, J=7.3 \mathrm{~Hz}, \mathrm{C}_{2}-\mathrm{CH}_{3}\right), 1.37(\mathrm{~m}, 1 \mathrm{H}, \mathrm{H}-$ $\left.5^{\prime}\right), 1.26\left(\mathrm{~m}, 1 \mathrm{H}, \mathrm{H}-7^{\prime}\right), 1.14\left(\mathrm{~s}, 3 \mathrm{H}, \mathrm{C}_{4}-\mathrm{CH}_{3}\right), 1.18\left(\mathrm{~s}, 3 \mathrm{H}, \mathrm{C}_{8}-\mathrm{CH}_{3}\right), 0.95(\mathrm{~d}$, $\left.3 \mathrm{H}, J=6.7 \mathrm{~Hz}, \mathrm{C}_{6}-\mathrm{CH}_{3}\right) ;{ }^{13} \mathrm{C} \mathrm{NMR}\left(100 \mathrm{MHz}, \mathrm{CDCl}_{3}\right) 171.7$ (s, C-1), 104.8 (s, C-9), 81.7 (d, C-3), 75.5 (s, C-8), $71.6(\mathrm{~s}, \mathrm{C}-4), 75.6$ (d, C-5), 71.6 (d, C12), 41.9 (t, C-5), 39.9 (t, C-7), 34.5 (d, C-2), 26.17 (q, $\left.\mathrm{C}_{4}-\mathrm{CH}_{3}\right), 25.0$ (q, $\mathrm{C}_{8}-\mathrm{Me}$ ), 23.4 (d, C-6), 21.6 (q, $\left.\mathrm{C}_{9}-\mathrm{CH}_{3}\right), 20.5$ (q, $\left.\mathrm{C}_{6}-\mathrm{CH}_{3}\right), 18.6$ (q, $\mathrm{C}_{2}-\mathrm{CH}_{3}$ ); EIMS $m / z$ (rel int.) 226 [M-CO $]^{+}$(26), 166 (36),123 (83), 109 (100); HREIMS calcd for $\mathrm{C}_{13} \mathrm{H}_{22} \mathrm{O}_{3}$ [M-CO ${ }^{+} 226.1569$, found 226.1573 .

\section{Acknowledgements}

This work was supported by grants from MICINN (AGL200913359-C02-01) and from Junta de Andalucía (P07-FQM-02689). We gratefully acknowledge Dr. Muriel Viaud from the UMR BIOGER, INRA (Versailles, France) for supplies $B$. cinerea mutant bcbot $2 \Delta$.

\section{References and notes}

1. Cutler, H. G.; Jacyno, J. M.; Harwood, J. S.; Dulik, D.; Goodrich, P. D.; Roberts, R G. Biosci., Biotechnol., Biochem. 1993, 57, 1980-1982.

2. Collado, I. G.; Aleu, J.; Hernández-Galán, R.; Hanson, J. R. Phytochemistry 1996, $42,1621-1624$.

3. Reino, J. L.; Durán-Patrón, R. M.; Daoubi, M.; Collado, I. G.; Hernández-Galán, R. J. Org. Chem. 2006, 71, 562-565.

4. Tani, H.; Koshino, H.; Sakuno, E.; Nakajima, H. J. Nat. Prod. 2005, 68, 1768-1772.

5. Tani, H.; Koshino, H.; Sakuno, E.; Cutler, H. G.; Nakajima, H. J. Nat. Prod. 2006, 69, $722-725$.

6. Fukui, H.; Shiina, I. Org Lett. 2008, 10, 3153-3156; Fukui, H.; Hitomi, S.; Suzuki, R. Ikeda, T.; Umezaki, K.; Tsuji, K.; Shiina, I. Tetrahedron Lett. 2008, 49, 6514-6517.

7. Shiina, I.; Fukui, H. Chem. Commun. 2009, 385-400.

8. Pinedo, C.; Wang, Ch.-M.; Pradier, J. M.; Dalmais, B.; Choquer, M.; Le Pecheur, P.; Morgant, G.; Collado, I. G.; Cane, D. E.; Viaud, M. ACS Chem. Biol. 2008, 3, 791-801.

9. Welmar, K.; Tschesche, R.; Breitmaier, E. Chem. Ber. 1979, 112, 3598-3602.

10. Suga, T.; Hirata, T.; Utsumi, R.; Yoshioka, T. J. Sci. Hiroshima Univer., Ser. A 1984 48, 75-79.

11. Bruns, W.; Horns, S.; Redlich, H. Synthesis 1994, 335-342.

12. Seco, J. M.; Quiñoa, E.; Riguera, R. Tetrahedron: Assymetry 2001, 12, 2915-2925. 13. Unpublished results

14. Steyn, P. S.; Vieggaar, R.; Wessels, P. L. J. Chem. Soc., Perkin Trans. 1 1981, 1298-1308 15. Sakuno, E.; Tani, H.; Nakajima, H. Biosci., Biotechnol., Biochem. 2007, 71, 2592-2595. 